\title{
Otomotiv sektöründe bütünleşik ergonomik risk değerlendirme uygulaması
}

\author{
Seren ÖZMEHMET TAŞAN", Burcu FELEKOĞLU \\ Dokuz Eylül Üniversitesi, Mühendislik Fakültesi, Endüstri Mühendisliği Bölümü, İzmir \\ Geliş Tarihi (Recived Date): 16.08 .2018 \\ Kabul Tarihi (Accepted Date): 26.12.2018
}

\section{Özet}

Günümüzde birçok ülkede iş ile ilgili kas ve iskelet sistemi rahatsızlıkları oluşumunun ergonomik risklere maruziyet ile ilişkili olduğu kanıtlanmıştır. Bu sebeple dünyada ve ülkemizde ergonomiye verilen önem giderek artmaktadır. Buna rağmen ergonominin işletmelerdeki uygulamaları ve bunların yapacağı etkiler tam olarak anlaşılamamış durumdadır. Bütünleşik ergonomik risk değerlendirme yaklaşımının uygulanması ve bu konunun önemini incelemek üzere yapılan bu çalışmada, bir otomotiv yan sanayii fabrikasında ana montaj hattı ve taşıma hattında ergonomik risk değerlendirme çalışması yapılmıştır. Çalışmada fabrikanın ergonomik yönergelerine uygun olacak şekilde ve kullanılacak yöntemlerin kısıtlarını göz önünde bulundurup, ele alınan hatlarda reaktif yöntemlerden Cornell Kas İskelet Rahatsızlık Anketi (CKIRA) ve proaktif yöntemlerden işletmeye özgü ergonomik kontrol listeleri (EKL) ve ergonomik hareket alanı (EHA) hesaplaması birlikte kullanılmıştır. Bu yöntemlerle ergonomik risk faktörleri değerlendirilmiştir ve bu risklerin azaltılması amacıyla iyileştirme önerilerinde bulunulmuştur. Kas iskelet sistemi rahatsızllklarına sebep olabilecek risklerin sistematik ve bütünleşik bir ergonomik çalışma ile meydana gelmeden tespit edilmesinin, doğru bir iş planı yapılmasının, hem maliyetler hem de kişi ve şirket bazında yaşanabilecek problemleri önlemek için gerekli olduğu tespit edilmiştir.

Anahtar kelimeler: Ergonomi, risk de ğerlendirme, reaktif yaklaşım, proaktif yaklaşım, kas iskelet sistemi rahatsızlıkları.

\footnotetext{
* Seren ÖZMEHMET TAŞAN seren.ozmehmet@deu.edu.tr, http://orcid.org/0000-0002-0633-9414 Burcu FELEKOĞLU, burcu.felekoglu@ deu.edu.tr, http://orcid.org/0000-0001-7414-9199
} 


\title{
Application of integrated ergonomic risk assessment in the automotive sector
}

\begin{abstract}
It has been proven in many countries today that occupational musculoskeletal disorders are associated with exposure to ergonomic risks. For this reason, the importance given to ergonomics in the world and in our country is increasing steadily. Nevertheless, the applications of ergonomics in the business and their effects are not fully understood. In this study, in an effort to investigate the importance of the integrated ergonomic risk assessment approach and its implications, an ergonomic risk assessment is performed on the main assembly line and transport line in an automotive subsidiary factory. Considering the limitations of the methods to be used and in accordance with the ergonomic guidelines of the factory, ergonomic risk factors are assessed by using Cornell musculoskeletal discomfort questionnaire $(C M D Q)$ as a reactive method and company specific ergonomic control list (ECL) and ergonomic motion area (EMA) calculations as proactive methods. Ergonomic risk factors were evaluated with these methods and suggestions for improvement were made in order to reduce these risks. It has been determined that pursuing a systematic and integrated ergonomic risk assessment approach by which work related musculoskeletal disorder risks can be detected and making a robust business plan is needed to prevent both costs and problems that can be experienced on a person and company basis.
\end{abstract}

Keywords: Ergonomics, risk assessment, reactive approach, proactive approach, musculoskeletal systems disorders.

\section{Giriş}

Meslek hastalıkları imalat ve hizmet sektörlerinde faaliyet gösteren ișletmelerin üretkenliğini olumsuz yönde etkilemekte ve çeşitli mali kayıplara neden olmaktadır. Ayrıca çalışanların yaşam kalitesinin düşmesine sebep olmaktadır. İş yaşamında gerek yapılan işin gerekse çalışma ortamının ergonomik uygunsuzlukları nedeniyle kaslar, tendonlar, ligamanlar ve diskler vb. yumuşak dokularda gözlenen kas iskelet sistemi rahatsızlıkları (KİSR), iş sağlığı kapsamında işe bağlı kas iskelet sistemi rahatsızlıkları (IKIISR) olarak adlandırılmaktadır [1]. İKISRR bazı kaynaklarda ergonomik rahatsızlıklar olarak da adlandırılmaktadır. Akut ya da kronik seyreden bu tür rahatsızlıkların oluşumlarında iş yerinde ağır yük kaldırma, tekrarlamalı ve/veya zorlamalı hareketler, vücudun kötü pozisyonlarda kullanımı ve ergonomik uygunsuzluklar vb. faktörler etkili olmaktadır. Çalışanların en önemli sağlık sorunları arasında olan ve iş verimliliğini azaltan İKİSR, çalışanın günlük hayatını olduğu kadar iş yaşamını da etkilemektedir.

İKİSR'in işletmeler ve çalışanlar üzerindeki etkileri konusunda bilinçlendirme çalışmaları, gelişmiş ülkelerde uzun senelerdir yapılmaktadır [2]. Gelişmekte olan ülkelerde ise bu tür çalışmalar daha çok yasal zorunluluklar, uluslararası ortaklı yapıda olmanın getirdiği çeşitli yükümlülükler vb. sebeplerle giderek artmaktadır. İKİSR etkileri ve bunları önleme/azaltma girişimleri tek bir çalışmayla çözülebilecek yapıda olmayıp sürekli ilgi gerektiren bir konudur. Gelişmiş ülkeler grubunu oluşturan AB bile günümüzde İKİSR'in etkilerinin tekrar su yüzüne çıkmasıyla 2014-2020 stratejik 
planına İKİSR'i yeniden dahil etmiş ve bu konularda tekrar araştırmalar yapmaya başlamıştır [3].

Ülkemizde İKİSR konusunda yapılan çalışmalar, 2007 yılında AB'nin İSG Haftası adı verilen "Yükü Hafifletin" kampanyası ile Çalışma Sosyal Güvenlik Bakanlığının periyodik olarak yayınladığı ISSG Dergisi'nde KISSR ve ergonomi konusunda özel bir sayının hazırlanmasıyla başlamıştır. Bu çalışmalarda ülkemizde İKİSR nedeniyle sakatlık sonucu gerçekleşen kayıp yıl miktarı olarak açıklanan IKIISR sakatlık yükünün nöropsikiatrik rahatsızlıklar ile çeşitli yaralanmalardan sonra \%9,9 ile meslek hastalıkları arasında üçüncü sırada geldiği görülmektedir [4]. 2012 yılında yürürlüğe giren 6331 sayılı İş Sağlığı ve Güvenliği (İSG) Kanunu ve takiben yayınlanan ilgili mevzuatla bu kapsamda yapılacak çalışmalar için yasal bir platform oluşturulmuştur. 6331 sayılı İSG Kanun' da risk değerlendirmesi “işyerlerinde var olan ya da dişarıdan gelebilecek tehlikelerin belirlenmesi, bu tehlikelerin riske dönüşmesine yol açan faktörler ile tehlikelerden kaynaklanan risklerin analiz edilerek derecelendirilmesi ve kontrol tedbirlerinin kararlaştırılması amacıyla yapılması gerekli çalışmalar” şeklinde tanımlanmıştır [5]. Ardından aynı yıl 28512 sayılı Resmi Gazete'de yayımlanan İş Sağlığı ve Güvenliği Risk Değerlendirmesi Yönetmeliği ile işletmelerde iş sağlı̆̆ ve güvenliği mevzuatına uygunluğun sağlanması ve çalışanların korunması için ilk adım olan 6331 sayılı İSG Kanunu'nda adı geçen risk değerlendirme çalışmalarının usul ve esasları düzenlenmiştir [6]. 2013 yılının başından itibaren tüm işyerlerine risk değerlendirme çalışması yapma zorunluluğu getirilmiştir. İş sağlığı ve güvenliği risk değerlendirmesi kapsamında incelendiğinde çalışanlarda görülen IKİSR'in azaltılması ve önlenmesi için çalışma ortamındaki ergonomik risklerin tanımlanarak işler için ergonomik risk analizlerinin yapılması işletmeler için çok önemli bir hale gelmektedir [7]. Fakat İKİSR ile karşılaşma sıklığı bu kadar yüksek olmasına rağmen, çalışanların en önemli sağlık sorunları arasında olan ve iş verimliliğini azaltan İKİSR'den ve olumsuz etkilerinden korunmak büyük ölçüde mümkünken ülkemizde, işletmeler ve çalışanlar tarafından konuya verilen önemin yeterli olmadığg görülmektedir [8].

Bu kapsamda, gelişigüzel ve yüzeysel şekilde yapılacak bir ortam değerlendirmesi ile iyileştirme önerilerinde bulunmak yerine İKİSR'a neden olan uygunsuz ergonomik koşulların belirlenmesi için bütünleşik bir yapıda sistematik ergonomik risk değerlendirme çalışmalarının yapılması ve ardından iyileştirme önerilerinde bulunulması çok büyük önem arz etmektedir.

Bu çalışmada, çalışanların hissettikleri KİSR ile çalışma ortamında bu rahatsızlıkların meydana gelmesindeki muhtemel ergonomik koşulların değerlendirildiği reaktif ve proaktif yöntemler eş zamanlı olarak bütünleşik bir yaklaşımla uygulanmıştır. Bu yaklaşımda reaktif yöntemler ve proaktif yöntemler aynı süreç içerisinde her ikisi de ayrı ayrı uygulanarak kullanılmıştır. Çoğunlukla gerçek hayat uygulamalarında sadece reaktif veya sadece proaktif yöntemler kullanılarak yapılan çalışmalar bulunmaktadır. $\mathrm{Bu}$ çalışmanın amacı daha sağlıklı ve gerçekçi bir ergonomik risk değerlendirme için her iki yöntemle bulunan sonuçların beraber ele alınarak değerlendirildiği bütünleşik bir yaklaşımın uygulanmasıdır. Proaktif yöntem ile uzman gözlemci ve çalışanlardan alınan bilgiler ve yapılan hesaplamalardan iş ve ortam ile ilgili ergonomik riskler değerlendirilmiş, reaktif yöntem ile çalışanların yaşadıkları kas iskelet rahatsızlıkları değerlendirilmiştir. Proaktif yöntem kapsamında, değişik bakış açılarıyla değerlendirme yapmaya imkan veren ve işletmeye ve/veya işe göre yapılandırılabilen ergonomik kontrol listeleri (EKL) ve ergonomik hareket alanı (EHA) hesaplaması kullanılmıştır. 
Reaktif yöntem kapsamında ise, vücut bölgelerine göre KİSR belirtilerini üç boyutta inceleyen, çalışanların kolaylıkla, ön bir eğitim gerekmeksizin ve kısa sürede doldurabileceği, Cornell Kas İskelet Rahatsızlık Anketi (CKİRA) kullanılmıştır. Gerçekleştirilen uygulama otomotiv yan sanayinde faaliyet gösteren bir işletmede taşıma ve montaj işlemleri için ayrı ayrı yapılmıştır ve sonuçlar değerlendirilerek iyileştirme önerilerinde bulunulmuştur.

\section{Ergonomik risk değerlendirme}

Çalışma ortamında belirlenen ergonomik risklerin değerlendirilmeleri İKİSR'in azaltılması ve önlenmesi açısından çok önemli bir adımdır. İKİSR'e sebep olan ergonomik risk faktörleri yükün özellikleri, postür, gürültü, titreşim gibi iş ile ilgili olabildiği gibi, kişinin yaşı, fiziksel durumu gibi kişiye özgü de olabilmektedir. Ergonomik risk faktörleri tanımlanırken risklerin tek tek etkilerinin yanında birleşik etkilerinin de göz önünde bulundurulması gereklidir [1].

Ergonomik riskler tanımlandiktan sonra bu riskleri analiz etmeye uygun ergonomik risk değerlendirme yönteminin seçilmesi gerekmektedir. Ergonomik risk değerlendirme yöntemlerinin sınıflandırması konusunda araştırmacılar farklı bakış açılarına sahiptir. Ergonomik risk değerlendirme için kullanılan yöntemleri literatür ve uygulama açısından inceleyen ilk tarama çalışması Pascual ve Naqvi [9] tarafından yapılmıştır. Bu çalışmada Kanada' da yapılan gerçek hayat uygulamaları araştırılmıştır. İşletmelerde bu tür uygulamaları hayata geçiren İSG uzmanlarına çeşitli sorular sorularak anket yöntemiyle veriler toplanmıştır. Verilerin değerlendirilmesi sonucunda, İSG uzmanlarının ergonomik risk değerlendirme konusunda aldıkları İSG uzmanlık eğitimlerindeki yetersiz bilgilendirme nedeniyle, ISG uzmanının tecrübe ve bilgilerini kullanarak gözlemci olarak veri toplayacağı ve değerlendireceği yöntemler yerine daha çok çalışanlardan rahatsızlıklar için bilgi toplayacak özbildirim yöntemlerinin kullanıldığı görülmüştür. Ayrıca bilimsel olarak geliştirilen ergonomik risk değerlendirme yöntemlerinin akademik amaçlı yapılan çalışmalardaki uygulanabilirlikleriyle gerçek hayatta işletmelerdeki uygulanabilirlikleri arasındaki uçuruma dikkat çekilmiştir. David [10] ve Özel ve Çetik [11] tarafından yapılan çalışmalarda ergonomik risk değerlendirme yöntemleri özbildirimler, sistematik gözlemler ve direkt ölçümler olarak, sistematik gözlemsel yöntemlere daha ayrıntılı yer verilerek, üçe ayrı kategoride incelenmiştir. Takala ve çalışma arkadaşları [12], 30 adet gözleme dayalı yöntemi sistematik olarak detaylı şekilde incelemiş ve 19 tane yöntemi geçerlilik, tekrarlanabilirlik ve fayda konusunda karşılaştırmalı olarak değerlendirmiştir. $\mathrm{Bu}$ çalışmada, en uygun ergonomik risk değerlendirme yönteminin sektöre, ihtiyaçlara ve kullanılacak yöntemin çıktılarının karar verme süreçlerini nasıl etkileyeceğine göre seçilmesi gerektiği vurgulanmıştır. Felekoğlu ve Özmehmet Taşan [1] tarafından yapılan çalışmada ise çeşitli ergonomik risk değerlendirme yöntemleri incelenerek bu yöntemler, proaktif ve reaktif amaçlı olmak üzere iki sınıfa ayrılmıştır. Proaktif yöntemler, sistem tasarımı ve sistemin çalışması aşamalarında sistematik gözlemsel yöntemler ve doğrudan ölçüm yöntemleri ile çalışanların yapması planlanan veya yaptıkları işlerin incelenerek bunların neden olabileceği risk faktörlerinin belirlenmesini ve değerlendirilmesini içermektedir. Reaktif yöntemler ise sadece sistem çalışmaya başladıktan sonra çalışanlardan alınan özbildirimler ve sağlık kayıtları ile ergonomik riskler sebebiyle meydana gelen rahatsızlıkların incelenmesini ve değerlendirilmesini 
içermektedir. Ayrıca, yazarlar ergonomik risk değerlendirmeyi etkin hale getirecek reaktif ve proaktif yöntemleri beraber içeren bir değerlendirme yaklaşımı geliştirmiş̦tir.

Ergonomik risk değerlendirme çalışmalarında, farklı bakış açılarıyla değerlendirme yapmaya imkan sağlayacak yöntemlerin seçilmesi çok önemlidir. İşletmelerin yürüttükleri risk değerlendirme çalışmalarında proaktif yöntemleri reaktif yöntemlerle destekleyerek değerlendirme yapması ve bunların sonucunda gerekli iyileştirme önerilerinde bulunması daha etkin sonuçlar elde etmek için gereklidir. Bu çalışmada, proaktif ve reaktif yöntemlerin bir arada kullanıldığı bütünleşik bir risk değerlendirme uygulaması yapılmıştır. Ergonomik risk değerlendirme yöntemi olarak, akademik uygulanabilirlik ve gerçek hayatta işletmelerde uygulanabilirlik arasındaki uçurumu kapatmak için proaktif yaklaşımlardan ergonomik kontrol listeleri (EKL) seçilmiş ve reaktif yaklaşımlardan özbildirimler kullanılmıştır.

İşletmenin tümüne ya da işletme içindeki bir bölüme uygulanabilecek şekilde geliştirilebilen ergonomik kontrol listeleri, işin, çalışma ortamının ve koşullarının ergonomik olarak uygunluğunun değerlendirilmesi amaciyla bir araya getirilmiş sorulardan oluşmaktadır [13]. Bu listeler, ergonomik açıdan sorunlu süreç, iş, donanım ve ortamların belirlenmesi, sürekli izlenmesi ve kontrol edilmesi amacıyla kullanılmak üzere geliştirilmektedir. EKL ile yapılan değerlendirme uzman gözlemcilerin veya çalışanların gözlemlerine dayanmaktadır. ILO, NIOSH ve OSHA vb. ulusal veya uluslararası kuruluşlar tarafından ergonomik kontrol amaçlı geliştirilen listeler farklı sektörlerde başarıyla uygulanmaktadır [14]. Ülkemizde ise iş sağlığı ve güvenliği risk değerlendirmesi kapsamında Çalışma Sosyal Güvenlik Bakanlığı tarafından, farklı sektörler için geliştirilen kontrol listelerinde ergonomik uygunluğun değerlendirilmesi için soru(lar) bulunmaktadır [15]. Genel olarak sektörler için geliştirilen listelerin yanında işletmeler kendi organizasyon, süreç ve işleri için kendilerine özel ergonomik kontrol listeleri geliştirerek kullanmaktadır. Örneğin otomotiv sektöründe faaliyet gösteren Volvo işletmesinde kullanmak üzere özel ergonomik kontrol listeleri geliştirmiştir [16]. Ergonomik risk değerlendirme yöntemleri arasından ergonomik kontrol listeleri, kolay uygulanması, uygulama ve analizi için eğitim gereksiniminin az olması ve işletmeye kalıcı belgeleme sağlaması açısından çoğunlukla tercih edilmektedir [17]. Ayrıca sistematik yöntemlerden REBA [18], OCRA [19], QEC [20] gibi bir kısmı sadece iş ile ilgili fiziksel risk faktörlerine odaklanırken; ergonomik kontrol listelerinin hem iş ile ilgili fiziksel hem de iklim koşulları ve gürültü gibi diğer risk faktörlerini de birlikte değerlendirmeye imkan vermesi işletmeler tarafından bu listelerin kullanılabilirliğini arttırmaktadır. Fakat unutulmamalıdır ki, işletmeye özel bir EKL geliştirilmesi sürecinde, geçmişte ve şu an yürütülen ergonomik çalışmaların detaylı olarak gözden geçirilmesi ve konuda uzman kişilerden görüş alınması çok önemlidir. Bu çalışmada kullanılacak olan EKL, ulusal ve uluslararası kuruluşlar tarafından geliştirilen genel amaçlı listeler ve otomotiv sektöründe bulunan diğer işletmelerin geliştirdiği özel listeler incelenerek işletmeye ve incelenecek süreç ve işe yönelik olarak işletme tarafından geliştirilmiştir.

Özbildirim yöntemleri ise çalışanın vücudundaki KISSR'leri kendisinin değerlendirdiği yöntemlerdir $[10,11]$. Bu tür yöntemler genellikle anket tabanlı olup en büyük avantajları; uygulama için eğitim gereksiniminin düşük olması, az kaynak kullanımı ve mümkün olabilen en geniş örneklem büyüklüğünü sunmalarıdır. Literatürde ve işletme uygulamalarında özbildirim yöntemlerinden sıklıkla kullanılanlardan bazıları şöyledir; Hollanda Kas İskelet Anketi [21], Cornell Kas İskelet Rahatsızlık Anketi [22], 
İskandinav Kas İskelet Anketi [23]. Ayrıca, değişik sistematik yöntemlerin bir arada kullanıldığ çalışmalar [24, 25] ve sistematik yöntemler ile özbildirim yöntemlerini beraber ele alan çalışmalar [26, 27] bulunmaktadır. Bu çalışmada, Türkçe geçerlilik ve güvenilirlik araştırması yapılmış olan Cornell Kas İskelet Rahatsızlık Anketi (CKİRA) kullanılacaktır.

\section{Otomotiv yan sanayinde yapılan uygulama çalışması}

$\mathrm{Bu}$ çalışma otomotiv yan sanayinde hizmet veren ana merkezi ABD'de olan çok uluslu bir şirketin Türkiye'de binek araçlar için bağlantı parçası üreten fabrikasında yapılmıştır. Şirketin dünya çapında bağlantı parçası üreten 100'e yakın fabrikası bulunmaktadır. Türkiye'de 30 yıldır faaliyet gösteren şirketin bu çalışmada incelenen fabrikasında 2000'e yakın mavi yaka operatör bulunmakta ve 20 yıldır bağlantı parçası üretimi yapılmaktadır. Şirketin yönetim politikası gereği bu çalışmada şirket adı ve ürünün detaylı bilgileri gizli tutulmuştur. Bu çalışmada, bağlantı parçası üretiminde IKISSR etkilerinin en fazla görüldüğü taşıma operatörleri ile montaj hattı operatörleri ele alınacaktır. $\mathrm{Bu}$ çalışmada kullanılacak bütünleşik ergonomik risk değerlendirme yaklaşımı ile sistemin tasarım ve işleyiş aşamasında risklerin değerlendirilmesini içeren bir proaktif yöntem ile sistem hayata geçirildikten sonra risklerin gerçekleşmesi sonucu meydana gelen rahatsızlık, hastalık vb. durumların incelenmesini içeren bir reaktif yöntem beraber ele alınmaktadır.

\subsection{Binek araçlar için bağlantı parçası ve üretimi}

Binek araçlarda elektrik güç ve dağıtım sistemlerinde kullanılan bağlantı parçaları motorun çalışması ve marş sistemine gerekli voltajın sağlanması gibi aracın temel fonksiyonları ve sinyal lambaları, enstrüman paneli, farlar gibi 1şık ve uyarı fonksiyonları için kullanılabildiği gibi müzik sistemi, elektrikli pencereler, çakmak, koltuk 1sıtma gibi konfor fonksiyonları için kullanılabilmektedir. Bu çalışmada bu tür amaçlarla kullanılan parçaları ifade etmek için bağlantı parçası ifadesi kullanılacaktır. $\mathrm{Bu}$ bağlantı parçaları araç tipine göre değiştiği gibi modelin versiyonuna göre de değişmektedir.

Çekme sistemi mantığıyla çalışan fabrikada bağlantı parçası üretiminde kesme, ön montaj ve montaj olmak üzere üç aşamalı bir üretim sistemi kullanılmaktadır. Üretim için gereken hammadde ve yarı mamulün bulunduğu deponun raflarında her parça için adres tanımlıdır. Böylece hatta malzeme taşıyan operatörlerin parçaları kolay bulması sağlanmış olmaktadır. Birinci aşama olan kesme aşamasında üretilecek bağlantı parçasına göre taşıma operatörleri tarafından depodan getirilen parçalar istenilen uzunluklarda kesilir. Kesimden çıkan parçaların bir kısmı ön montaja bir kısmı ise montaja taşıma operatörleri tarafından taşınır. Kesme aşamasından sonra montaj hattını besleyen ön montaj istasyonlarında yarı mamüller üretilir. Üretilen yarı mamüller, montaj hatlarına taşınmak üzere levhalara asılır. Montaj aşamasında ise kesme aşamasından gelen parçalar ile ön montaj aşamasından gelen yarı mamüller kullanılarak 15 üretim bandında bağlantı parçası montajı gerçekleştirilmektedir. Montaj sırasında operatörler ayakta çok sayıda işlem gerçekleştirmektedir.

\subsection{Bütünleşik ergonomik risk değerlendirme yaklaşımı}

$\mathrm{Bu}$ çalışmada hem proaktif hem de reaktif yöntemleri içeren bütünleşik bir ergonomik risk değerlendirme yaklaşımı kullanılacaktır. Ergonomik risklerin etkileri ortaya 
çıkmadan risklerin değerlendirilmesi için proaktif ergonomik değerlendirme yaklaşımı olarak taşıma ve montaj işleri için EKL kullanılmıştır ayrıca montaj işleri için EHA hesaplaması da yapılmıştır. EKL, ergonomik olarak iş tasarımlarının değerlendirilmesi ve ürün/süreç değișikliklerinin iș tasarımı üzerinde yarattığ değișimleri ergonomik açıdan izlemek için kullanılan araçlardır. EKL, işler için özel olarak geliştirilmiş olup ilgili bölümlerde detaylı olarak anlatılacaktır. EKL'de bulunan toplam değerlendirme puanının, şirketin stratejik planında belirtilen alt limitler ele alındığında, en az 80 puan olması istenmektedir. Bu değer 80'den az ise "iş durdurulmalı ve acil müdahale yapılmalı", 80 ile 84 arasında ise "en çok iki gün içerisinde çözüm bulunmalı", 85 ve 94 arasında ise "en çok iki hafta içerisinde çözüm bulunmalı", 95 ile 99 arasında ise "en çok bir ay içerisinde çözüm bulunmalı" ve 100 ise "iş tasarımı ergonomik olarak uygun yapılmıştır" anlamlarını ifade etmektedir. Tablo 1'de EKL sonucunda bulunan puanının değerlendirme ölçeği gösterilmiştir.

Tablo 1. EKL için değerlendirme ölçeği.

\begin{tabular}{l|l}
\hline Toplam Değerlendirme Puanı & Alıması gereken aksiyon \\
\hline 80 'den az & İşi durdur ve acil önlem al \\
\hline $80-84$ arası & En çok 2 gün içerisinde çözüm bulunmalı \\
\hline $85-94$ arası & En çok 2 hafta içerisinde çözüm bulunmalı \\
\hline $95-99$ arası & En çok 1 ay içrisinde çözüm bulunmalı \\
\hline 100 & Sorun yok \\
\hline
\end{tabular}

Montaj işleri için EKL'ye ek olarak yapılan EHA hesaplamasında operatörün parça üzerinde gerçekleştireceği işlemler ve insan vücudunun güç bölgesi dikkate alınarak, hareket alanı sınırlarına göre değerlendirme yapılmakta ve montaj yüzeyi üzerinde parçanın ergonomik açıdan uygun şekilde konumlandırılması hedeflenmektedir.

Ergonomik risklerin etkileri, ortaya çıkardığı rahatsızlık, hastalık vb. durumların değerlendirilmesi için reaktif ergonomik değerlendirme yaklaşımı olarak taşıma ve montaj işleri için CKİRA kullanılmıştır. Cornell Üniversitesi'nde geliştirilen CKİRA çalışanın dolduracağı bir öz-bildirim formudur [22]. CKİRA, 20 vücut bölgesi için rahatsızlığın sıklığı, şiddeti ve işe etkisi üzerinde bilgi toplamak için kullanılacaktır. Bu anketin geçerlilik ve güvenirlik değerlendirme çalışması Erdinc ve çalışma arkadaşları [28] tarafından yapılmıştır. Bu anketin hem oturarak hem de ayakta çalışanlar için düzenlenmiş formları mevcuttur. Bu çalışmada incelenen işlerin hepsinin ayakta yapıldığı göz önünde bulundurularak CKİRA'nın ayakta yapılan işler için hazırlanan versiyonu kullanılmıştır (Şekil 1). 


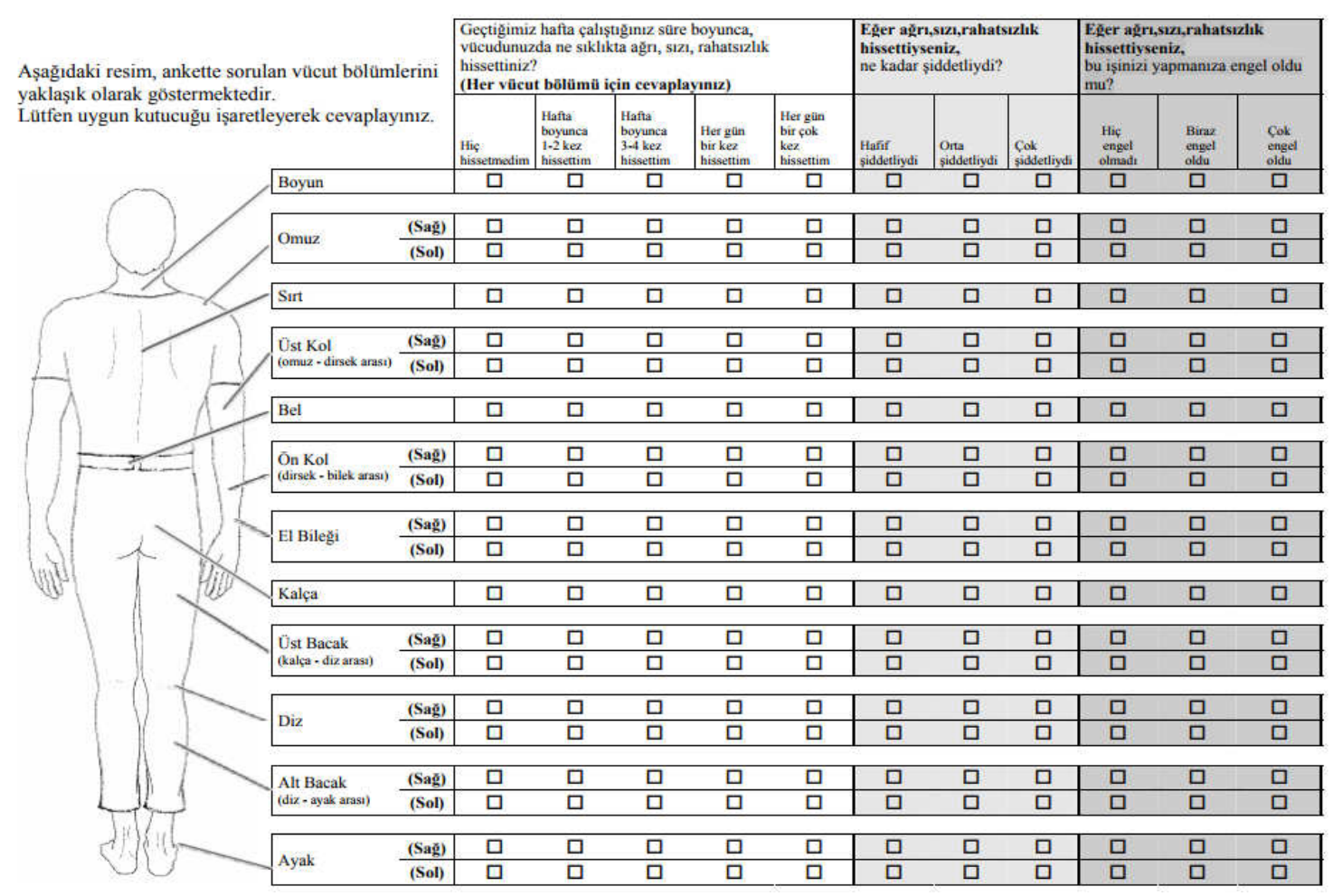

Şekil 1. Ayakta çalışan erkek operatörler için kullanılan CKİRA [28].

CKİRA'da üç ana soru bulunmaktadır. İlk olarak "Geçtiğimiz hafta boyunca vücudunuzda ne sıklıkla ağrı, sızı, rahatsızlık hissettiniz?" sorusu sorulur. Çalışanın bu soruya cevap olarak "Hiç hissetmedim, Hafta boyunca 1-2 kez hissettim, Hafta boyunca 3-4 kez hissettim, Her gün $1 \mathrm{kez}$ hissettim ve Her gün birçok kez hissettim" cevaplarından birini vermesi istenir. Bu cevapların ağırlıkları sırasıyla " $0,1,5,3,5,5$, 10" olarak belirlenmiştir. İkinci olarak ise "Eğer ağrı, sızı, rahatsılılı hissettiyseniz ne kadar şiddetliydi?" sorusu sorulur. Bu soruya cevap olarak ise "Hafif şiddetliydi, Orta şiddetliydi, Çok şiddetliydi”" cevaplarından birini vermesi istenir. Bu cevapların ağırlıkları sırasıyla "1, 2, 3" olarak belirlenmiştir. Son olarak ise "Eğer ağrı, sızı, rahatsızlık hissettiyseniz, bu işinizi yapmanıza engel oldu mu?" sorusu sorulur. Bu soruya cevap olarak ise "Hiç engel olmadı, Biraz engel oldu, Çok engel oldu" cevaplarından birini vermesi istenir. Bu cevapların ağırlıkları sırasıyla "1, 2, 3" olarak belirlenmiştir. 18 vücut bölgesinin her biri için verilen cevaplar ile ağırlıklar kullanılarak her bir bölgeye ait risk puanı hesaplanmaktadır. Ayrıca ilk soruya verilen cevaplar değerlendirilerek vücut bölgelerine göre KİSR prevelansları hesaplanabilmektedir.

\section{Taşıma işleri için bütünleşik ergonomik risk değerlendirme}

Fabrikada taşıma işlerinden sorumlu yaşları 25 ile 45 arasında değişen ve üç vardiya çalışan toplamda 28 erkek taşıma operatörü bulunmaktadır. Taşıma operatörleri depodan kesime giden ve kesimden çıkan parçaların ihtiyaç duyulan üretim aşamalarına teslimini sağlamak ile görevlidir. Çekme sisteminin kullanıldığı depo alanında taşıma operatörlerinin montaj hatlarına parça veya yarı mamül taşımaları sırasında, planlı bir sırayı takip etmeleri gereken rotalar vardır. Diğer bölümlere zamanında taşıma yapmak için bu rotaların belirlendiği çizelgeye uygun olarak çalışmak çok önemlidir. Taşıma 
operatörleri öne eğilme, yukarı uzanma, merdiven çıkma-inme, araba itme-çekme, uzun-kısa mesafe yürüyüssleri gibi faaliyetlerde bulunmaktadır.

Taşıma işleri için yapılan iki adımlı ergonomik risk değerlendirme çalışmasında sırasıyla; (a) operatörler gözlemlenerek toplanan veriler ile Taşıma Ergonomik Kontrol Listesi (TEKL) doldurulmuş ve (b) çalışanlardan toplanan veriler ile yapılan CKİRA sonuçlarına göre rahatsızlık yaşanan vücut bölgeleri, rahatsızlıkların ne sıklıkla yaşandığı ve rahatsızlıkların işe engel olma derecesi hesaplanmıştır. Tüm bu incelemelerden elde edilen veriler birlikte ele alınarak bütünleşik ergonomik risk değerlendirme yapılmış ve daha sonra iyileştirme önerilerinde bulunulmuştur. Bu analiz sırasında sistematik olarak yapılanlar Şekil 2'de gösterilmiştir.

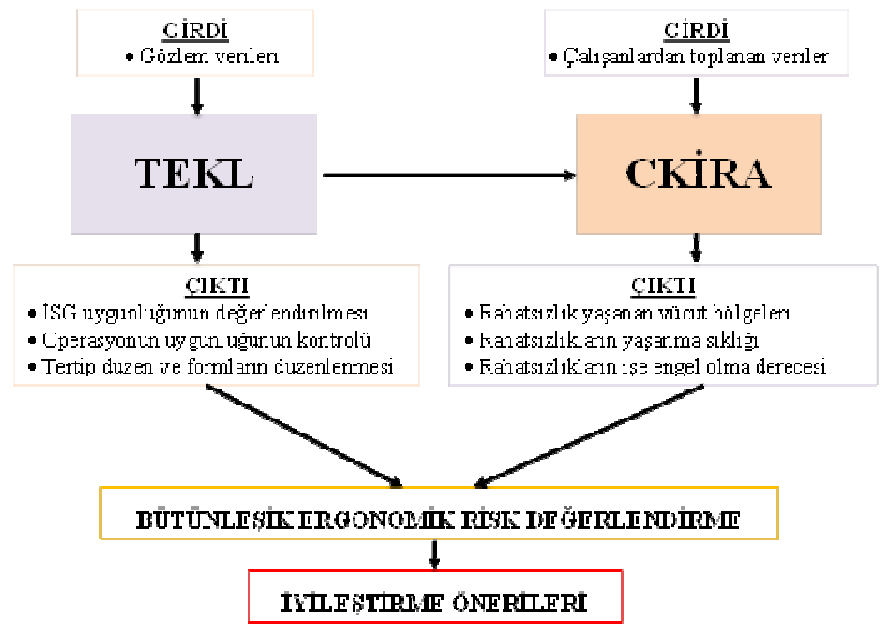

Şekil 2. Taşıma operatörleri için kullanılan bütünleşik ergonomik risk değerlendirme yaklaşımı.

\subsection{Taşıma ișleri için ergonomik kontrol listesi}

Taşıma işleri için işletme tarafından geliştirilen ergonomik kontrol listesi, taşıma işi sırasında ürün, ekipman ve süreçlerin meydana getirebileceği riskleri yada durumları belirleyerek ergonomik risk değerlendirmesi yapmak amacıyla kullanılan bir araçtır. Değerlendirme sırasında TEKL'de bulunan iş güvenliği ve işçi sağlığı (3 soru), operasyon uygulanması (15 soru), tertip düzen ve formların düzenlenmesi (4 soru), kontrol talimatı (1 soru) ve operasyon sonrası riskler (2 soru) başlıkları altında 5 bölümden oluşan toplam 25 soru için "Evet" ve "Hayır" yanıtlarından uygun olanlar işaretlenmektir. Her soruya "Evet" yanıtı verildiğinde 4 puan verilmektedir. TEKL'de bulunan toplam değerlendirme puanı için Tablo 1'de verilmiş olan ölçek kullanılmaktadır. TEKL sonucunda bulunan toplam değerlendirme puanının, şirketin stratejik planında belirtilen alt limitler ele alındığında, en az 80 puan olması istenmektedir.

Taşıma işleri değerlendirilerek TEKL doldurulduğunda iş güvenliği ve işçi sağlığ1 başlığı altındaki 3. Soru (Merdiven operatör tarafından iş güvenliğini tehdit edecek şekilde sarkarak kullanılıyor mu?) ve tertip düzen ve formların düzenlenmesi başlığı altındaki 4.soru (Operatör parçaların etiketli olan taraflarını görünür şekilde yerleştiriyor mu?) dışında diğer tüm sorulara "Evet" cevabı verildiği görülmüştür. Değerlendirme için puan hesabı yapıldığında (92 puan) taşıma işlerinin tasarımının ergonomik açıdan 
şuan için kabul edilebilir olduğu fakat bu tasarımın ergonomik açıdan en çok 2 hafta içerisinde iyileştirilmesi gerektiği sonucuna varılabilir.

\subsection{Taşıma işleri için CKİRA}

CKİRA formunu 3 vardiyada çalışan tüm taşıma operatörleri eksiksiz doldurmuştur. Genel olarak baktığımızda taşıma operatörlerinin rahatsızlık prevelanslarına göre KISR'in en çok boyun $(\% 32,14)$, bölgesinde görüldüğü tespit edilmiştir. Ayrıca CKİRA sonuçları her bir vardiya için rahatsızlık prevelanslarına göre değerlendirildiğinde; A vardiyasında çalışan operatörlerin en çok bel $(\% 55,6)$, B vardiyasında çalışan operatörlerin en çok boyun $(\% 44,4)$ ve C vardiyasında çalışan operatörlerin de en çok boyun (\%40) bölgelerinde rahatsızlık yaşadıkları belirlenmiştir. Tablo 2'de tüm çalışanlar için ve her bir vardiyada çalışanlar için en yüksek rahatsızlık prevelansına sahip ilk 5 vücut bölgesi ve en yüksek risk puan yüzdesine sahip ilk 5 vücut bölgesi gösterilmektedir.

Tablo 2. Taşıma operatörleri için en yüksek KİSR prevelansına ve risk puan yüzdesine sahip ilk beş vücut bölgesi.

\begin{tabular}{|c|c|c|c|}
\hline \multicolumn{4}{|c|}{ Genel } \\
\hline Vücut Bölgeleri & Risk Puan Yüzdesi (\%) & Vücut Bölgeleri & Prevalans (\%) \\
\hline Bel & 44,49 & Boyun & 32,14 \\
\hline Boyun & 41,95 & Bel & 32,14 \\
\hline Alt Bacak & 4,06 & Alt Bacak & 14,29 \\
\hline Omuz & 1,96 & Omuz & 14,29 \\
\hline Diz & 0,31 & Sirt & 7,14 \\
\hline \multicolumn{4}{|c|}{ A Vardiyası için } \\
\hline Vücut Bölgeleri & Risk Puan Yüzdesi (\%) & Vücut Bölgeleri & Prevalans $(\%)$ \\
\hline Bel & 95 & Bel & 55,6 \\
\hline Boyun & 0,9 & Boyun & 11,1 \\
\hline Alt Bacak & 0,9 & Sirt & 11,1 \\
\hline Diz & 0,9 & Alt Bacak & 11,1 \\
\hline Sirt & 0,5 & Diz & 11,1 \\
\hline \multicolumn{4}{|c|}{ B Varidyası için } \\
\hline Vücut Bölgeleri & Risk Puan Yüzdesi (\%) & Vücut Bölgeleri & Prevalans $(\%)$ \\
\hline Boyun & 71,9 & Boyun & 44,4 \\
\hline Alt Bacak & 10 & Omuz & 22,2 \\
\hline Bel & 3,3 & Alt Bacak & 22,2 \\
\hline Omuz & 2 & Sağ Üst Kol & 11,1 \\
\hline Sağ Üst Kol & 0,6 & Bel & 11,1 \\
\hline \multicolumn{4}{|c|}{ C Vardiyası için } \\
\hline Vücut Bölgeleri & Risk Puan Yüzdesi (\%) & Vücut Bölgeleri & Prevalans $(\%)$ \\
\hline Boyun & 54,1 & Boyun & 40 \\
\hline Bel & 35,1 & Bel & 30 \\
\hline Omuz & 4,3 & Omuz & 20 \\
\hline Ön Kol & 0,8 & Alt Bacak & 10 \\
\hline Alt Bacak & 0,3 & Ön Kol & 10 \\
\hline
\end{tabular}

\subsection{Taşıma işleri için genel değerlendirme}

Taşıma işleri için yapılan gözlemler sonucu taşıma operatörlerinin sıklıkla elle çekme ve itme, eğilme, uzun mesafe yürüme, uzanma, merdiven çıkma/inme ve yük taşıma faaliyetlerinde bulundukları belirlenmiştir. Bütünleşik değerlendirme kapsamında; taşıma işlerinde proaktif yaklaşımla değerlendirme yapıldığında TEKL sonucu bulunan 92 puan, stratejik planda alt limit olarak belirtilen 80 puandan yüksek olduğu için taşıma işlerinin ergonomik açıdan uygun tasarlandığı sonucuna varılabilir. Fakat reaktif yaklaşımla değerlendirme yapıldığında taşıma operatörlerinde KISSR'in görüldüğü 
birçok durumun ortaya çıktığı CKİRA prevelans değerlerinden açıkça görülmektedir. Vücut bölgelerine göre KİSR yaşayan taşıma operatörlerinin sayısal olarak dağılımı Şekil 3'de gösterilmiştir.

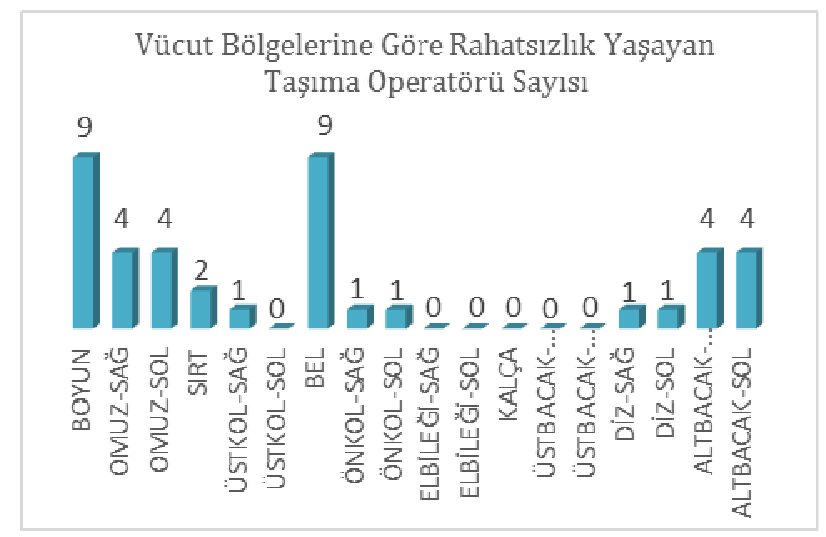

Şekil 3. Vücut bölgelerine göre rahatsızlık yaşayan operatörlerin sayısal dağılımı.

CKİRA sonuçları kullanılarak hesaplanan risk puanlarına göre tüm taşıma operatörleri için genel bir değerlendirme yapıldığında en yüksek risk puan yüzdesine sahip ilk beş vücut bölgesinin boyun, bel, alt bacak, omuz ve sırt olduğu bulunmuştur. Tüm vücut bölgeleri için risk puan yüzdeleri Şekil 4'te gösterilmektedir.

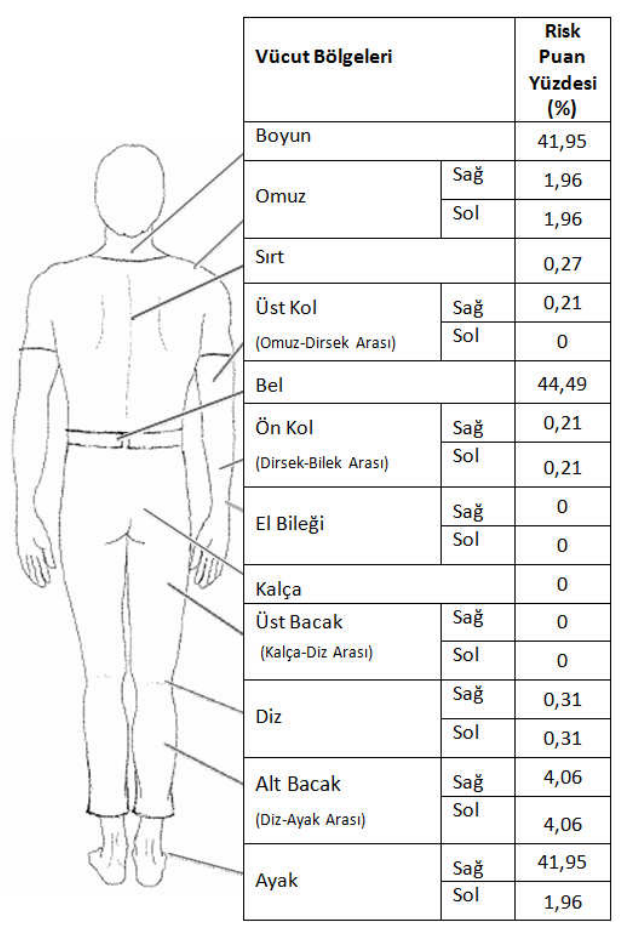

Şekil 4. Taşıma operatörlerinin CKİRA risk puan yüzdelerinin insan vücudu üzerinde gösterimi.

Ayrıca CKİRA sonucunda bulunan risk puanları kullanılarak, A,B ve C vardiyalarında çalışan taşıma operatörleri arasında istatistiksel olarak anlamlı bir fark olup olmadığını test etmek amacıyla tek yönlü Anova testi uygulanmıştır. Testin sonuçları değerlendirildiğinde $\alpha=\% 5$ önem düzeyinde taşıma işleri için $A, B$ ve $C$ vardiyalarında 
çalışan operatörler arasında istatistiksel açıdan bir fark olmadığı ortaya çıkmıştır $(p=1>0,05)$.

$\mathrm{Bu}$ çalışma sonucunda ergonomik risk değerlendirme için sadece proaktif değerlendirmenin yeterli olmadığı muhakkak reaktif bir değerlendirme ile desteklenmesi ve beraber değerlendirilmesi gerektiği açıç̧a görülmektedir. Bu çalışmada proaktif ve reaktif değerlendirme sonuçları beraber değerlendirilmiş ve taşıma operatörlerinde görülen İKİSR'lerin azaltılması için aşağıdaki önerilerde bulunulmuştur;

- Elle parça taşımayı en aza indirmek adına forklift gibi elektriksel araç ya da faaliyetin daha rahat gerçekleştirilmesi için daha uygun taşıma ekipmanlarından faydalanılmalıdır.

- Mevcut durumda itme ve çekme faaliyetlerinde kullanılan araçlar yenilenmeli dönen aksamları ile ilgili bakımlar yapılmalı ve daha rahat kullanılabilir hale getirilmelidir.

- Taşıma mesafelerini en aza indirecek şekilde düzenleme yapılmalıdır. Ayrıca taşıma operatörlerinin gereğinden fazla mesafe yürümemeleri için tekrar taşıma rotalarının belirlenerek bunların operatörlere eğitimlerle öğretilmesi ve rotaların kullanımının takip edilmesi önemlidir.

- Ayrıca taşıma araçlarının aracı itmeyi ve çekmeyi kolaylaştırmak için zemin ile arasındaki sürtünmeyi minimuma indirgeyecek şekilde yeniden tasarlanması ancak kaymaması için fren sisteminin de eklenmesi ve bunun yanı sıra operatörün ekstra güç kullanmasını da minimum seviyeye getirmek için aracın yapıldığı malzemenin hafif ancak mukavemeti fazla olacak şekilde tasarlanması önerilmiştir.

- Yolların bakımının düzenli bir şekilde yapılmasına dikkat edilmelidir. Taşıma trafiğginin düzenlenerek çakışmaların azaltılması sağlanmalıdır.

- Depolarda parçaların bir kısmının çok alçak seviyelerde olması nedeniyle uzun veya kısa boylu gözetmeden tüm operatörlerin eğildiği gözlemlenmiştir. Bu tip eğilme hareketleri operatörlerde sıklıkla gözlemlenen bel ağrılarına neden olmaktadır. Eğilmeleri azaltacak şekilde depolardaki parçaların operatörlerin güç bölgesi içinde kalacak şekilde depo yerleşimlerinin düzeltilmesi önerilmektedir. Operatörlerin parçaları aldıkları yüzey yüksekliklerinin güç bölgesi içerisinde kalmasını sağlamak için manuel/otomatik yüksekliği ayarlanabilir tezgahlar veya asansörlü sistemler kullanılmalıdır.

- Düzenli eğitim ve denetim eksikliğinden dolayı operatörlerin merdivenleri düzgün ve doğru bir şekilde kullanmadıkları, işe ve yüksekliğe uygun basamağı kullanmadan parça koyma/alma işlemleri için gereğinden fazla uzandıkları ve bu nedenle boyun, omuz ve kol bölgelerinde ağrıların yaşandığı gözlemlenmiştir. Taşıma operatörlerine belirli zamanlarda tekrar edecek şekilde merdiven/basamak kullanma ve ayrıca elle taşıma/kaldırma eğitimi verilmelidir. Ayrıca operatörlerin hem çalışma arkadaşlarını denetlemeleri hem de kendi öz denetimlerini yapmaları konusunda farkındalıkları arttırılmalıdır.

\section{Montaj işleri için bütünleşik ergonomik risk değerlendirme}

Fabrikada seri üretim öncesi çalışmaların yapıldı̆̆ı montaj hattında yaşları 25 ile 50 arasında değişen ve tek vardiya halinde çalışan 14 kadın ve 18 erkek toplamda 32 montaj operatörü bulunmaktadır. $\mathrm{Bu}$ operatörler montaj işlemlerini ayakta gerçekleştirmektedir. 
Montaj hattındaki işler için yapılan üç adımlı ergonomik risk değerlendirme çalışmasında sırasıyla; (a) montaj hattında yapılan işlerin metod analizlerinden alınan veriler ile Ergonomik Hareket Alanı (EHA) hesaplaması yapılmış, (b) operatörler gözlemlenerek toplanan veriler ile Montaj Hattı Ergonomik Kontrol Listesi (MHEKL) doldurulmuş ve (c) çalışanlardan toplanan veriler ile yapılan CKİRA sonuçlarına göre rahatsızlık yaşanan vücut bölgeleri, rahatsızlıkların ne sıklıkla yaşandığı ve rahatsızlıkların işe engel olma derecesi hesaplanmıştır. Tüm bu incelemelerden elde edilen veriler birlikte ele alınarak bütünleşik ergonomik risk değerlendirme yapılmış ve daha sonra iyileştirme önerilerinde bulunulmuştur. Bu analiz sırasında sistematik olarak yapılanlar Şekil 5’te gösterilmiştir.

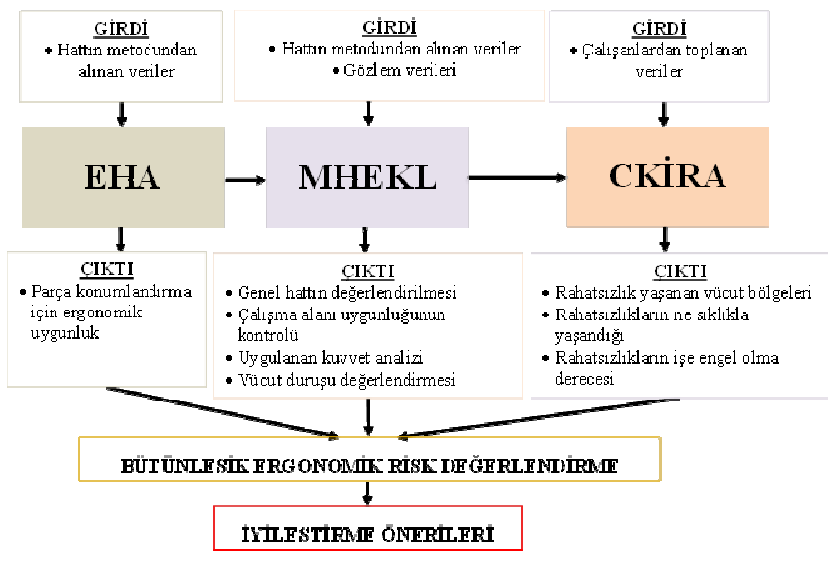

Şekil 5. Montaj operatörleri için kullanılan bütünleşik ergonomik risk değerlendirme yaklaşımı.

\subsection{Montaj için Ergonomik Hareket Alanı (EHA) hesaplaması}

Parça üretiminde son aşama olan montaj, ayakta duran operatör tarafından bağlantı yerleştirme işlemlerinin yapılmasını içermektedir. Montaj işinin tasarımı yapılırken montaj operatörünün parça üzerinde gerçekleştireceği işlemler sırasında uzanma ve eğilmelerin ergonomik sınırlar içerisinde olması hedeflenmektedir. Montaj için hareket alanı sınırları belirlenirken insan vücudunun güç bölgesi dikkate alınarak ergonomik açıdan hareket alanları, baş üstü, omuz-baş arası, omuz-gögüs arası, gögüs-bel arası, bel, bel-kalça arası, kalça-diz arası ve diz altı olarak sekiz grupta değerlendirilmektedir. Ayrıca, bu hareket alanlarında yapılan işlerin ergonomik uygunluğunu belirlemek için sirasiyla \%30, \%60, \%80, \%95, \%100, \%80, \%60, \%30 yüzdesel ağırlıkları kullanılmaktadır. EHA hesaplaması yapılırken operatörün parça üzerinde gerçekleştirdiği bağlantı yerleştirme işlemi sayısı ile bu işlem sırasında hareketin gerçekleştirildiği alanın yüzdesel ağırlığı çarpılmakta ve bulunan değer toplam bağlantı yerleştirme işlemi sayısına bölünerek yüz ile çarpılmaktadır.

EHA hesabı yapılmadan önce parçanın montaj yüzeyi üzerine konumlandırması yapılmaktadır. Montaj yüzeyinin yerden yüksekliği hesaplanarak sıklıkla alt ve üst sınırları omuz ve kalça hizasında olacak şekilde konumlandırılmaktadır. Parçanın montaj yüzeyi üzerine ilk konumlandırması yapıldıktan sonra EHA için değerlendirmeye geçilmektedir. Öncelikle metod dosyaları kullanılarak montaj yüzeyi üzerindeki her bir bölgede yapılan bağlantı yerleştirme sayıları belirlenmektedir. Tüm bölgeler için yerleştirme sayıları belirlendikten sonra bu sayılar bulundukları hareket alanlarındaki yüzdesel ağırlıklarla çarpılmakta ve tüm değerler toplanarak bağlantı 
yerleştirme işlemi için EHA değeri bulunmaktadır. Şirketin stratejik planında, bağlantı yerleştirme için bulunan EHA değerinin \%80'den büyük olması istenmektedir. Eğer bu değerler düşük çıkarsa montaj yüzeyi üzerinde yapılan parça konumlandırmasında değişime gidilip tekrar yüzdeler hesaplanmaktadır.

$\mathrm{Bu}$ çalışmada ele alınan parça için montaj yüzeyi, yerden yüksekliği $850 \mathrm{~mm}$ olacak şekilde konumlandırılmıştır. Her hareket alanında yapılan montaj işlemlerine göre metod dosyası incelendiğinde, bel-kalça arası bölgede 10 adet, bel bölgesinde 20 adet, göğüs-bel arası bölgede 16 adet ve son olarak omuz-göğüs arası bölgede 22 adet bağlantı yerleştirme işlemi yapıldığı görülmektedir. Bu veriler doğrultusunda EHA hesaplaması sonucunda bağlantı yerleştirme için bulunan EHA değerinin \%89,4 olduğu görülmüştür. Bu değer \%80'den büyük olduğu için montaj işinin ergonomik sınırlar dahilinde uygun bir şekilde tasarlandığını söyleyebiliriz.

\subsection{Montaj işleri için ergonomik kontrol listesi}

Montaj işleri için işletme tarafından geliştirilen ergonomik kontrol listesi, montaj hattında ürün, ekipman ve süreçlerin meydana getirebileceği riskleri yada durumları belirleyerek ergonomik risk değerlendirmesi yapmak amacıyla kullanılan bir araçtır. Değerlendirme sırasında MHEKL'de bulunan genel (7 soru), çalışma alanı (2 soru), kuvvet (12 soru) ve vücut duruşu (12 soru) başlıkları altında 4 bölümden oluşan toplam 33 soru için "Evet", "Hayır" ve "Soru Geçerli değil" yanıtlarından biri işaretlenmektir. Toplamda MHEKL'de 100 puan bulunmaktadır. MHEKL'de verilen her cevabın toplam değerlendirme puanına etkisi aynı değildir. Her soruya verilen cevabın toplam değerlendirme puanına olan etkisi işletmenin iş sağlığı güvenliği politikasını da içeren stratejik planındaki önem düzeylerine göre belirlenmiştir. Örneğin bir soruya verilen cevap, montaj hattının acil durdurulmasını ve müdahale edilmesini gerektiriyorsa bu cevabın toplam puana etkisi düşük (+0 puan) olup eğer soruya verilen cevap ergonomik uygunsuzluk açısından çok önemli değil ve müdahale edilmesini gerektirmiyorsa bu cevabın toplam puana etkisi yüksek (+6 puan) tir. MHEKL'de bulunan toplam değerlendirme puanı için Tablo 1'de verilmiş olan ölçek kullanılmaktadır. MHEKL'de bulunan toplam değerlendirme puanının, şirketin stratejik planında belirtilen alt limitler ele alındığında, en az 80 puan olması istenmektedir.

Montaj hattındaki metod incelenerek ve işler gözlemlenerek MHEKL doldurulduğunda tüm sorulara "Evet" cevabı verildiği görülmüştür. Değerlendirme için puan hesabı yapıldığında (100 puan) montaj işlerinin ergonomik açıdan uygun tasarlandığı sonucuna varılabilir.

\subsection{Montaj işleri için CKİRA}

CKİRA formunu tek vardiyada çalışan tüm kadın ve erkek montaj operatörleri eksiksiz doldurmuştur. Genel olarak baktığımızda montaj operatörlerinin rahatsızlık prevelanslarına göre KİSR'in en çok sağ el bileği $(\% 56,25)$ bölgesinde görüldüğü tespit edilmiştir. Ayrıca CKİRA sonuçları cinsiyetler için rahatsızlık prevelanslarına göre değerlendirildiğinde; kadın operatörlerin en çok el bileği (\%71) ve erkek operatörlerin en çok el bileği (\%44) bölgelerinde rahatsızlık yaşadıkları belirlenmiştir. Tablo 3 'de tüm çalışanlar için ve ayrıca kadın erkek için en yüksek rahatsızlık prevelansına sahip ilk 5 vücut bölgesi ve en yüksek risk puan yüzdesine sahip ilk 5 vücut bölgesi gösterilmektedir. 
Tablo 3. Montaj operatörleri için en yüksek KİSR prevelansına ve risk puan yüzdesine sahip ilk beș vücut bölgesi.

\begin{tabular}{|c|c|c|c|}
\hline \multicolumn{4}{|c|}{ Genel } \\
\hline Vücut Bölgeleri & Risk Puan Yüzdesi (\%) & Vücut Bölgeleri & Prevalans $(\%)$ \\
\hline El Bileği-Sağ & 50,44 & El Bileği-Sağ & 56,25 \\
\hline El Bileği-Sol & 34,57 & El Bileği-Sol & 53,12 \\
\hline Boyun & 4,6 & Bel & 18,75 \\
\hline Bel & 3,51 & Boyun & 15,63 \\
\hline Ön Kol & 2,54 & Ön Kol & 15,63 \\
\hline \multicolumn{4}{|c|}{ Kadın operatörler için } \\
\hline Vücut Bölgeleri & Risk Puan Yüzdesi (\%) & Vücut Bölgeleri & Prevalans (\%) \\
\hline El Bileği-Sağ & 52,16 & El Bileği-Sağ & 71,4 \\
\hline El Bileği-Sol & 30,5 & El Bileği-Sol & 64,3 \\
\hline Boyun & 6,8 & Boyun & 28,6 \\
\hline Ön Kol-Sağ & 3,5 & Ön Kol-Sağ & 28,6 \\
\hline Ön Kol-Sol & 3,5 & Ön Kol-Sol & 28,6 \\
\hline \multicolumn{4}{|c|}{ Erkek operatörler için } \\
\hline Vücut Bölgeleri & Risk Puan Yüzdesi (\%) & Vücut Bölgeleri & Prevalans (\%) \\
\hline El Bileği-Sağ & 45,05 & El Bileği-Sağ & 44,4 \\
\hline El Bileği-Sol & 45,05 & El Bileği-Sol & 44,4 \\
\hline Sirt & 6,07 & Bel & 16,7 \\
\hline Bel & 3,48 & Sirt & 16,7 \\
\hline Boyun & 0,07 & Boyun & 5,6 \\
\hline
\end{tabular}

\subsection{Montaj işleri için genel değerlendirme}

Montaj işleri için yapılan gözlemler sonucu, montaj operatörlerinin sürekli ve çoğunlukla sabit konumda ayakta durarak parça üzerinde tekrarlı bağlantı yerleştirme faaliyetlerinde bulundukları belirlenmiștir. Bütünleşik değerlendirme kapsamında; taşıma işlerinde proaktif yaklaşımla değerlendirme yapıldığında parça üzerine bağlantı yerleştirme işlemleri için EHA hesaplamalarında bulunan değer $(\% 89,4) \% 80$ 'den büyük olduğu için ve MHEKL sonucu bulunan 100 puan, değerlendirme ölçeğinde "iş tasarımı ergonomik olarak uygun yapılmıştır" düzeyinde olduğu için montaj işlerinin ergonomik açıdan uygun tasarlandığı sonucuna varılabilir. Fakat reaktif yaklaşımla değerlendirme yapıldığında, montaj operatörlerinde KISSR'in görüldügü birçok durumun ortaya çıktığı CKİRA prevelans değerlerinden açıkça görülmektedir. Vücut bölgelerine göre KİSR yaşayan montaj operatörlerinin sayısal olarak dağılımı Şekil 6' da gösterilmiştir.

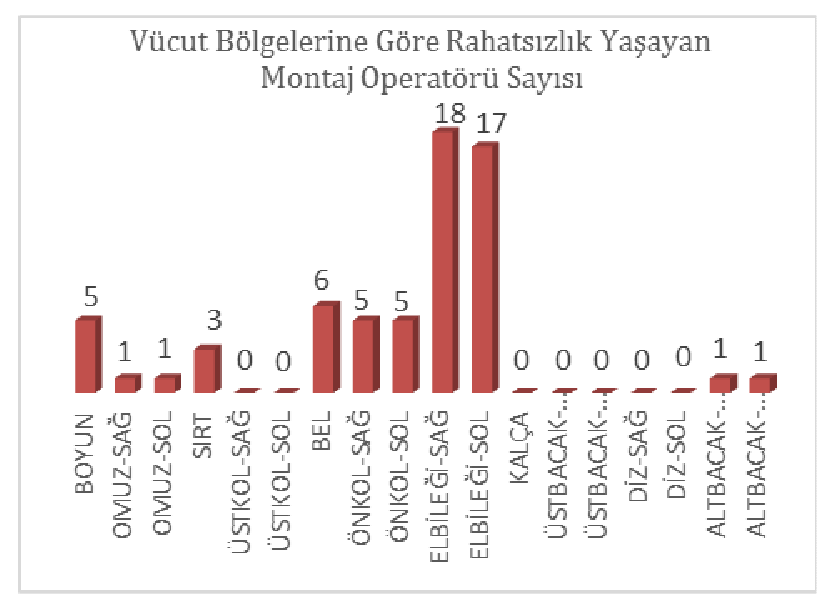

Şekil 6. Vücut bölgelerine göre rahatsızlık yaşayan operatörlerin sayısal dağılımı. 
CKİRA sonuçları kullanılarak hesaplanan risk puanlarına göre tüm montaj operatörleri için genel bir değerlendirme yapıldığında en yüksek risk puan yüzdesine sahip ilk beş vücut bölgesinin sağ el bileği, sol el bileği, boyun, bel ve ön kol olduğu bulunmuştur (Şekil 7).

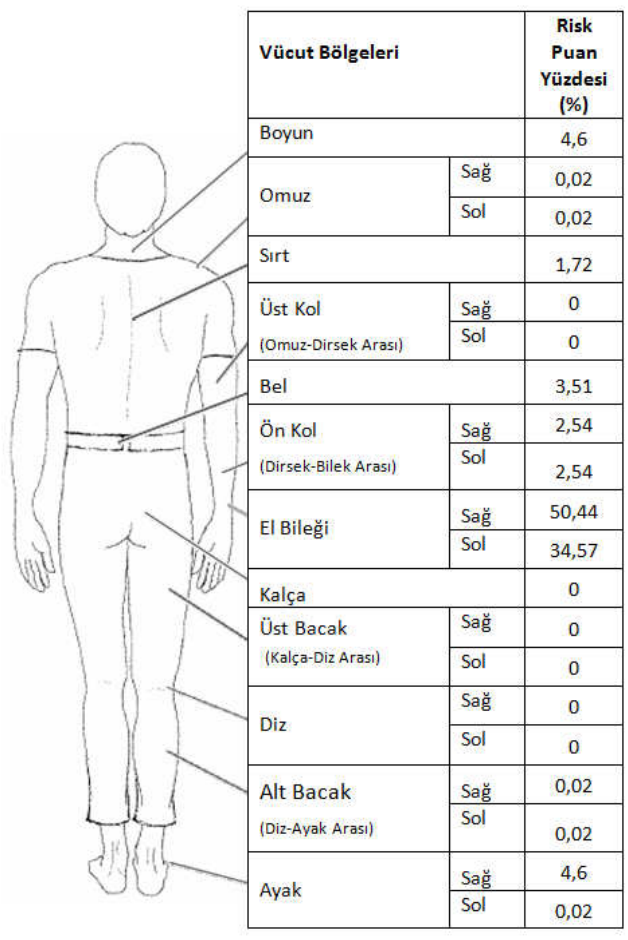

Şekil 7. Montaj operatörlerde CKİRA risk puan yüzdelerinin insan vücudu üzerinde gösterimi.

Ayrıca CKİRA sonucunda bulunan risk puanları kullanılarak, cinsiyetlerine göre çalıșan montaj operatörleri arasında istatistiksel olarak anlamlı bir fark olup olmadığını test etmek amacıyla tek yönlü Anova testi uygulanmıştır. Testin sonuçları değerlendirildiğinde $\alpha=\% 5$ önem düzeyinde taşıma işleri için kadın ve erkek çalışan operatörler arasında istatistiksel açıdan bir fark olmadığı ortaya çıkmıştır $(\mathrm{p}=1>0,05)$.

Montaj işlerinde proaktif yöntemler olarak kullanılan EHA ve MHEKL yöntemleri iş tasarımını dikkate alarak değerlendirme sağlarken, reaktif yöntem olarak kullanılan CKİRA yöntemi ise tasarlanan işin uygulamaya geçirilmesinden sonra oluşan durumu dikkate alarak değerlendirme sağlamaktadır. Proaktif ve reaktif yöntemlerin sonuçları arasındaki fark, montaj işlerinin gerçek hayatta uygulanması sırasında iş tasarımında öngörülmeyen risklerin olabileceğini göstermektedir.

$\mathrm{Bu}$ çalışma sonucunda ergonomik risk değerlendirme için sadece proaktif değerlendirmenin yeterli olmadığı, muhakkak reaktif bir değerlendirme ile desteklenmesi ve beraber değerlendirmesi gerektiği açıkça görülmektedir. Bu çalışmada proaktif ve reaktif değerlendirme sonuçları beraber değerlendirilmiş ve montaj operatörlerinde görülen İKİSR'lerin azaltılması için aşağıdaki önerilerde bulunulmuştur;

- El bileklerinde yaşanan ağrı uzun ve tekrarlı bağlantı yerleştirme işlemlerinden kaynaklanmaktadır. Bu soruna yönelik bir iyileştirme sağlamak için montaj 
yüzeyinin eğimi bilekleri yormayacak şekilde tasarlanmalıdır. Ancak bilek ağrısının montaj hattı için maksimum düzeyde olduğunu düşünürsek bu ağrının temel sebebinin tekrarlı hareketler olabileceğini söyleyebiliriz. Montaj işlerinde mümkün olduğunca her iki elin dengeli şekilde kullanılması sağlanmalıdır. Bu doğrultuda, sağ el bileğinin üzerindeki işlem sayısının azaltılması ve orantılı olarak paylaştırılması bu konuda geliştirilen bir çözüm önerisi olacaktır, önerinin metot açısından yapılabilirliği uzman çalışanlar ile değerlendirilmelidir. Ayrıca, çalışma saatlerinde iyileştirilmeler yapılmalıdır. Öncelikle birikimli yorulmayı önlemek için sık ve kısa dinlenme molaları verilecek şekilde çalışma süreleri düzenlenmelidir.

- Elleri kullanmak için en uygun pozisyonun güç bölgesi içerisinde olduğu düşünüldüğünde montaj sırasında yapılan işlerin bu bölge içerisinde gerçekleştirilmesini sağlamak için montaj yüzeyinin yüksekliği çalışanlara göre ayarlanabilir olmalıdır.

- MHEKL'ne operatörün yaptığı işlerin ergonomik değerlendirmesi ile ilgili sorular eklenerek bu listenin güncellenmesi sağlanabilir, böylece MHEKL tek başına uygulandığında bile daha doğru sonuçlar verebilecek şekilde düzenlenebilir. Örneğin operatörün bağlantı yerleştirme işlemini ne sıklıkla yaptığı ve ne kadar süre ile bu işleme devam ettiği bilgileri de ergonomik değerlendirme sırasında ele alınmalıdır.

\section{Tartışma ve Sonuç}

Ergonominin iş yaşamında önemi gittikçe artmaktadır. Bugün birçok ülkede ergonomi, iş ile ilgili KİSR oluşumu riskinin azaltılmasıyla ilişkilendirilmektedir. Ancak ülkemizde konuyla ilgili uygulamaların azlığ 1 ve bu uygulamalarda yaşanan sorunlar, ergonominin işletmelerdeki ve İSG kavramı içindeki yerinin halen tam olarak anlaşılamadığını göstermektedir.

Bu çalışmada, bir otomotiv yan sanayii işletmesinde taşıma ve montaj operatörlerinin gerçekleştirdiği faaliyetlerdeki ergonomik riskler CKİRA yöntemi ile reaktif olarak incelenmiştir. Ardından EKL yöntemi ve EHA hesabı ile operatörlerin gerçekleştirdiği işlerin ergonomik risk değerlendirmesi proaktif olarak yapılmıştır. Proaktif değerlendirme sonuçlarına göre taşıma ve montaj bölümlerinde herhangi bir ergonomik uygunsuzluğun bulunmadığı ortaya çıkmıştır. Ancak reaktif değerlendirme göz önüne alındığında ilgili bölümlerde çalışan operatörlerde ergonomik risklerden kaynaklanan KİSR'lere rastlandığı açıkça görülmektedir. Bu çalışmada bütünleşik değerlendirme yaklaşımı kullanılarak sadece uzman gözlemlerine dayanan proaktif yöntemlerle değil çalışanlarda görülen KISSR'leri de inceleyen reaktif yöntemlerle toplanan verilerle de değerlendirme yapılmış ve ardından risklerin etkilerini önlemek/azaltmak için iyileştirilme önerilerinde bulunulmuştur.

$\mathrm{Bu}$ çalışma sonucunda görüldüğü gibi ergonomik çalışmalarda farklı bakış açıları kazandıracak değerlendirme yöntemlerinin seçilmesi çok önemlidir. İşletmelerin proaktif yöntemleri reaktif yöntemlerle destekleyerek bütünleşik ergonomik risk değerlendirme çalışmaları yapması ve bunların sonucunda iyileştirilme önerileri geliştirmesi gereklidir. Ayrıca, reaktif yöntem sonuçlarına göre işletmenin gelecekte kullanacağı proaktif yöntemi revize etmesi ve şirket stratejilerini ergonomi ve ISG birlikteliğinde tekrar yapılandırması gereklidir. Ergonomi, işletmelerin İSG politikaları içerisinde mutlaka yer almalı ve çalışma koşullarının geliştirilmesi için bu politikalar, 
işletme stratejileriyle bütünleştirilmelidir. İnsanların çalıştı̆ğ her ortamda ergonomi bir zorunluluk değil, bir felsefe haline getirilmelidir.

\section{Kaynaklar}

[1] Felekoğlu, B. ve Özmehmet Taşan, S., İş ile ilgili kas iskelet sistemi rahatsızlıklarına yönelik ergonomik risk değerlendirme: Reaktif/proaktif bütünleşik bir sistematik yaklaşım, Gazi Üniversitesi Mühendislik-Mimarlık Fakültesi Dergisi, 32, 3, 777-793, (2017).

[2] Podniece, Z.. Work-related musculoskeletal disorders: prevention report, European Agency for Safety and Health at Work, Belgium, (2008).

[3] European Agency for Safety \& Health at Work (EU-OSHA), Second European survey of enterprises on new and emerging risks (ESENER-2), 2014. https://osha.europa.eu/sites/default/files/publications/documents/esener-iisummary-en.PDF, (01.04.2018).

[4] Budakoğlu, İ. ve Akgün, H. S., Kas İskelet Sistemi Hastalıklarının Dünyadaki ve Ülkemizdeki Hastalık Yükü, İş Sağlığı ve Güvenliği Dergisi, 34, 20-23, (2007).

[5] İSG., İş Sağlığı ve Güvenliği Kanunu, Kanun No. 6331, T. C. Resmi Gazete, 28339, 30.06.2012.

http://www.mevzuat.gov.tr/MevzuatMetin/1.5.6331.pdf, (01.04.2018).

[6] İSG-RDY., İş Sağlı̆̆ı ve Güvenliği Risk Değerlendirmesi Yönetmeliği, T. C. Resmi Gazete, 28512, 29.12.2012.

http://www.mevzuat.gov.tr/Metin.Aspx?MevzuatKod=7.5.16925\&MevzuatIliski $=0 \&$ sourceXmlSearch, (01.04.2018).

[7] Hermans, V. ve Peteghem, J. V., The Relation Between OSH and Ergonomics: A 'Mother-Daughter' or "Sister-Sister" Relation, Applied Ergonomics, 37, 4, 451-459, (2006).

[8] Ayan, B., Montaj hattında ergonomik risk unsurlarının incelenmesi: Otomotiv sektörüne yönelik bir uygulama, Uzmanlık Tezi, TC Çalışma Ve Sosyal Güvenlik Bakanlığı, İş Sağlığı Ve Güvenliği Genel Müdürlüğü, Ankara, (2015).

[9] Pascual, S. A. ve Naqvi, S., An investigation of ergonomics analysis tools used in industry in the identification of work-related musculoskeletal disorders, International Journal of Occupational Safety and Ergonomics, 14, 2, 237245, (2008).

[10] David, C. G., Ergonomic Methods for Assessing Exposure to Risk Factors for Work-Related Musculoskeletal Disorders, Occupational Medicine, 55, 190199, (2005).

[11] Özel, E. ve Çetik, O., Mesleki Görevlerin Ergonomik Analizinde Kullanılan Araçlar ve Bir Uygulama Örneği, Dumlupınar Üniversitesi Fen Bilimleri Enstitüsü Dergisi, 122, 41-56, (2010).

[12] Takala, E-P., Pehkonen, I., Forsman, M., Hansson, G-Å., Mathiassen, S. E., Neumann, W. P., Sjøgaard, G., Veiersted, K. B., Westgaard, R. H. ve Winkel, J., Systematic evaluation of observational methods assessing biomechanical exposures at work, Scandinavian Journal of Work, Environment \& Health, 36, 1, 3-24, (2010).

[13] MacLeod, D., The ergonomics kit for general industry, CRC Press, Boca Raton FL, (2006).

[14] Easterby, R. S., Ergonomics Checklists: An Appraisal, Ergonomics, 10, 5, 549556, (1967). 
[15] ÇSGB-Kontrol Listeleri,

https://www.csgb.gov.tr/isggm/contents/hizlierisim/yayinlar/ (01.04.2018).

[16] Munck-Ulfsfält, U., Falck, A., Forsberg, A., Dahlin, C. ve Eriksson, A. Corporate ergonomics programme at Volvo car corporation. Applied Ergonomics, 34, 1, 17-22, (2003).

[17] Ayoğlu, F. N., Kıran, S. ve Güler, Ç., Ergonomide denetim listeleri in Güler Ç., Sağlık Boyutuyla Ergonomi, Palme Yayıncılık, Ankara, (2004).

[18] Higgnet, S. ve Mcatamney, L., Technical Note, Rapid Entire Body Assessment. Applied Ergonomics, 31, 2, 201-205, (2000).

[19] Occhipinti, E., OCRA: A concise index for the assessment of exposure to repetitive movements of the upper limbs, Ergonomics, 41, 9, 1290-1311, (1998).

[20] David, G., Woods, V., Li, G. ve Buckle, P., The development of the Quick Exposure Check (QEC) for assessing exposure to risk factors for work-related musculoskeletal disorders, Applied Ergonomics, 39, 1, 57-69, (2008).

[21] Hildebrandt, V. H., Bongers, P. M., Van Dijk, F. J. H., Kemper, H. C. G. ve Dul, J., Dutch Musculoskeletal Questionnaire: description and basic qualities, Ergonomics, 44, 12, 1038-1055, (2001).

[22] Hedge, A., Morimoto, S. ve McCrobie, D. Effects of keyboard tray geometry on upper body posture and comfort, Ergonomics, 42, 10, 1333-1349, (1999).

[23] Kuorinka, I., Jonsson, B., Kilbom, A., Vinterberg, H., Biering-Sørensen, F., Andersson, G. ve Jørgensen, K., Standardised Nordic questionnaires for the analysis of musculoskeletal symptoms, Applied ergonomics, 18, 3, 233-237, (1987).

[24] Sevimli, M., Ulusu, H. A., ve Gündüz, T., Pirinç paketleme işinde çalışanların çalışma koşullarının ergonomik risk analizleri ile geliştirilmesi, Balıkesir Üniversitesi Fen Bilimleri Enstitüsü Dergisi, 20, 1, 38-54, (2018).

[25] Plantard, P., Shum, H. P., Le Pierres, A. S., ve Multon, F., Validation of an ergonomic assessment method using Kinect data in real workplace conditions, Applied ergonomics, 65, 562-569, (2017).

[26] Gönen, D., Oral, A., Ocaktan, M. B., Karaoğlan, A. D., ve Cicibaş, A., Bir transformatör işletmesinde montaj ünitesinin ergonomik analizi, Sakarya University Journal of Science, 21, 5, 1067-1080, (2017).

[27] Chowdhury, N., Aghazadeh, F., ve Amini, M., Ergonomic assessment of working postures for the design of university computer workstations, Occupational Ergonomics, 13, 1, 37-46, (2017).

[28] Erdinç, O., Hot, K. ve Özkaya, M., Turkish version of the Cornell Musculoskeletal Discomfort Questionnaire: Cross-cultural adaptation and validation, Work, 39, 3, 251-260, (2011). 